\title{
Technical Note: Methodology and Methods
}

Words of Passage is based on multi-sited ethnography, which adapts the classical features of qualitative fieldwork-a researcher's long-term engagement with a location that cultivates familiarity with local language and sociocultural life-to the exploration of processes that unfold across multiple sites (Burawoy et al. 2000; Dick and Arnold 20r 7 b; Hannerz 2003; Marcus 1995). This type of ethnography places at its center analysis of the interconnections between the present and various historical, imaginative, and geographical "beyonds." As such, it involves research in two or more locations linked by a practice, such as migration. My research involved over twenty-four months of continuous fieldwork between June 2000 and September 2002, first in small towns in Chester County, Pennsylvania, and then in Uriangato, Guanajuato, Mexico. My period of intensive fieldwork was book-ended by several preliminary field trips to both locations in 1997 and 1999 and numerous follow-up research trips between 2003 and 2005. Since that time I have maintained informal contact with the people with whom I grew the closest, in particular the members of my host family. However, the period of my formal research terminated in 2005 .

Therefore my ethnographic research offers a window onto a period just before three significant changes related to Mexico-US migration and the political economy that links these countries. First is the mass deportations that began in 2006 under George W. Bush's Operation Endgame, a process that accelerated under Barack Obama, who deported more undocumented immigrants than any other US president, and continues apace under Donald J. Trump. During the decades that most shaped the migration of my research participants-the I97os to the early 2000 - the US government did not engage in mass de- 
portations, as it had done before and has done since. Because migrants from Mexico make up the largest percentage of undocumented migrants in the United States-and because they are the focus of US antiimmigrant politics (Chávez 20I5; De Genova 2005; Dick 20Irb)—mass deportations affect Mexican migrant communities to a greater degree than other groups. The current period of mass deportations heralded a new era of immigration policy crackdowns. Since 2006, there has been a wave of state and municipal anti-immigrant laws (Varsanyi 20I0), colloquially described as policies of "self-deportation." Such policies seek to make conditions so unbearable for undocumented migrants that they opt to leave. In addition, they promote the criminalization of Mexican migrants, or anyone perceived to be Mexican, regardless of legal status (Dick 2OI Ib, 20I2). These crackdowns have left migrants and their relations in fear of separation. Rather than encouraging "self-deportation," they have in fact encouraged, however unwittingly, an existing trend toward the settlement-oriented migration of families, as people chose to "shelter in place." Nearly half of US households headed by undocumented migrants contain children who are US citizens, many of whom have never been to their parents' country of origin (Hernández-León and Zúñiga 20r6; Passel and Cohn 2009). This makes the prospect of returning the family to Mexico complicated and undesirable, even as conditions of life worsen for migrants in the United States.

The recent immigration policy crackdowns have coincided with the second major change that has occurred since my research period ended: an intensification of the Drug War in Mexico. This war has led to a dramatic increase in violence in certain parts of Mexico, including Michoacán, a state that borders Guanajuato and is a mere twenty minutes south of Uriangato. This conflict has spilled over into Uriangato, which, though not the site of the extensive violence seen elsewhere, has experienced assassinations of those involved in the drug trade. I have not returned to Uriangato in over ten years due to concern for my safety. Because of the increase in violence, many migrants are also reticent to return to Mexico and, indeed, are motivated to bring their family to the United States, despite the immigration crackdowns. Finally, these changes happened in concert with a third transformation: the stagnation of the US economy, which - though a long-term trend-was made sharply worse by the Great Recession of 2008. This economic slowdown has served to legitimate and justify immigration crackdowns, often in the name of protecting jobs for "American workers," as we see in 
the rhetoric of Donald J. Trump. And it has helped bring Mexico-US migration to a net zero, even putting it in negative numbers for some years (Gonzalez-Barrera 2015). Together these changes have produced new dimensions of migration that this book cannot address, such as the challenges faced by Mexican public schools as they seek to integrate the children of migrants, many of whom have limited or no ability to speak Spanish (Hernández-León and Zúñiga 2016).

In part because my ethnographic research terminated before these changes took hold, this book cannot be and is not an ethnography of the processes that shape contemporary migration between Mexico and the United States. But even if my research could be revealing of these processes, I would still not make them the focus of this book. As I explain in the introductory chapter, Words of Passage addresses a lacuna in the study of Mexico-US migration: how the production of representations of migration has long been central to nation-building and the production of inequality in Mexico. That is, I am more concerned with the ways migration shapes nonmigratory processes, especially the forms of national belonging and socioeconomic mobility to which working-class people in Mexico have access. For this reason, even though I conducted dual-sited fieldwork, this ethnography is focused on Mexico and how migration shapes the social world in Uriangato. Representations of migrants have played a key role in informing the production of "proper Mexicanness" (Mexicanidad) since at least the late nineteenth century for both state actors and people in Mexico's migrant communities. This process shapes people's access to the resources that allow for mobility. These representations have enduring features that have not disappeared in the intervening years since my ethnographic research ended.

Thus the data presented in this work continue to be relevant to understanding how such representations shape Mexicanidad. Indeed, as I argue in chapters 3 to 5 , forms of diasporic belonging, which are only furthered by the contemporary period of immigration crackdowns and families separated by a fear of moving across the US-Mexico border, are a distinguishing feature of "being Mexican" for working-class people. Overall, then, Words of Passage is a study of mobility and its politics understood holistically, as pertaining not only to geographical movements-"migration"-but to social and imaginative mobility as well (cf. Berg 2015). This is an underconsidered and important perspective, especially as the physical and social mobility of people across the globe is increasingly politicized and problematized, as discussed in the conclusion. 


\section{A Note on Terminology}

During my graduate studies, I was often asked if my project focused on "documented" or "undocumented" migrants—or whether I looked at settlement-oriented "immigration" or seasonal "migration." I always resisted answering these questions or placing them at the center of my research because they presuppose and help legitimate boundaries between groups and processes that do not exist empirically (De Genova 2002). Over the course of their lifetimes, migrants may move in and out of migratory and "immigratory" patterns (cf. Hondagneu-Sotelo 1994). They could spend twenty years as seasonal migrants, returning to Mexico every year for a few months, then spend another twenty years as immigrants, living principally in the United States, and finally decide to retire in Mexico. In much the same way, migrants can move in and out of legal statuses. They may begin migrating illegally then be legally contracted as guest workers, only to return to undocumented status later (cf. Ngai 2004). And this is only one of many possible scenarios. In a given community of Mexican migrants, any number of migratory patterns and legal statuses will be unfolding in close proximity. Some people return to Mexico each year for several weeks and thus follow a more migratory (seasonal) pattern, while others return once every four years and thus follow a more immigratory (settlement-oriented) pattern. Movement patterns are rarely definitive, as they exist in dynamic tension with ever-shifting life trajectories and geopolitics. For this reason, and in keeping with the terminological tradition of contemporary studies of global mobility (e.g., Basch et al. 1994; Berg 20I5; Smith 2006; Urry 2007), I refer to cross-border movements as "migration" to convey the sense of open-ended dynamism.

In terms of US legal status, there is no such thing as a bounded group of documented migrants who live apart from undocumented migrants (De Genova 2005; Dick 20Irb). Rather, their lives are intertwined and mutually informing. Mexican nationals with US legal permanent residency inhabit the same social space with temporary guest workers, naturalized citizens, US citizens by birth, and undocumented migrantsoften within a single household. A nuclear family with three children could have a US citizen father, a mother in the United States on a temporary spousal permit, a child without documents, a child with legal permanent residency, and a child born in the United States. Such sociolegal complexity is not uncommon; indeed, 4 million US-born children lived in such "mixed status" households in 2008 (Passel and Cohn 2009). 
When we consider that the majority of Mexican migrants who now have US legal status either used to be undocumented or have spouses or parents who were once undocumented, the supposedly sharp division between documented and undocumented becomes duller still. Indeed, many of the migrants I worked with in Chester County fit this profile. Initially a migration largely of undocumented sojourner migrants, this migration became a "mixed status" family migration in the early I990s. This change was a result of the Immigration Reform and Control Act of 1986, which gave US legal status to millions of Mexican families (Durand and Massey 2003) but was not accessible to all families, as I explain in chapter 4. Moreover, studies of policy crackdowns have shown over and over that they affect not only undocumented migrants but anyone who fits the ethnoracial and linguistic profile of an unauthorized migrant, regardless of actual legal status (Balderrama and Rodríguez 1995; De Genova 2005; Dick 20r rb; Ngai 2004). Thus, despite the frequent claims of anti-immigrant policy makers that they "have no problem with legal immigrants," their policies have a negative impact on people of all statuses, including citizens. Therefore, while I address US legal status where relevant, this book intentionally resists the reification of the divide between "documented" and "undocumented," representing these statuses and their effects as interwoven.

\section{Methodological Approach}

As intimated above, the methodology that centrally undergirds Words of Passage is dual-sited ethnography-first in Chester County and then in Uriangato. Although in recent decades multi-sited ethnography has been acknowledged as essential to the study of migration (see the discussion in Dick and Arnold 20I7b), there are still very few works based on research in both the sending country and receiving country (but see Abrego 20I4; Gamio 1930; Hirsch 2003; Lattanzi Shutika 20II; Smith 2006). Yet this methodological approach has several concrete benefits. Conducting field research in Chester County allowed me to use a method that George Marcus (1995: 106) calls "follow the people," which involves developing a network of social relations that piggybacks on the networks of migrants. My connections with transnational families helped me build the foundation of a research and social life in Uriangato. The people I lived with in Uriangato are the relatives of a family I worked with in Chester County. As with many newly arrived mi- 
grants in the United States who receive support from more long-term migrants (cf. Hondagneu-Sotelo 1994; Massey et al. 1987), relatives of my research participants in Pennsylvania helped me get oriented to the routines of life in Uriangato. Moreover, my relationships with people in Chester County helped make my presence in Uriangato comprehensible, helping me gain an audience with people who became not only research participants but friends. Building a life out of relationships with families was central to forestalling negative readings of my presence as a gringa (Dick 2017). As I explain in chapter 2, rooting my research in family allowed me to enact a respectable womanhood that mitigated against prevalent stereotypes about immoral US women.

But I centered my research in family life for more than practical reasons. Family relations play a central role in shaping migration processes (Abrego 2014; Castellanos 20IO; Chávez 2017a; Hirsch 2003; Hondagneu-Sotelo 1994; Massey et al. 1987; Rouse 1991, 1992, 1995; Smith 2006). Words of Passage further elaborates, in particular, scholarship that examines the role of family-internal difference in migration. Early research on family networks (e.g., Massey et al. 1987) entails a cooperative model of households that does not attend to power differentials inside families. Subsequent research has highlighted, for instance, that gender difference shapes access to networks and other family resources (Castellanos 20I0; Goodson-Lawes I993; Hirsch 2003; Hondagneu-Sotelo 1994; Rouse 1992). This research shows that migration typically emerges through family conflict, in which potential migrants contend with family members' resistance to their migration. Gender plays a crucial role in determining the degree of resistance to their migration desires, a pattern that I found replicated in people's talk of migration (see chapter 4). Beyond this, as chapters 2-5 show, the cultivation of family life is foundational to how Uriangatenses understand and enact national belonging and thus is the key social arena in which these processes unfold.

Another driving methodological principle of my work was a commitment to giving back to the people who participated in my research. Anthropology and sociocultural studies of language have a long-standing tradition of engaging in reciprocal research relationships that make research useful to research participants (Bucholtz et al. 20I4). Most Uriangatenses have a strong desire to learn English, so the main way I gave back was by offering free English as a Second Language (ESL) classes, having worked as an ESL teacher between college and graduate school. In Chester County my ESL teaching consisted of several night 
classes for adults, which I ran through my field research in Pennsylvania. I was also an in-home English tutor for several stay-at-home mothers. I taught the formal classes in the basement of an affordable housing office that worked largely with Mexican migrants. In the fall of 2000 I began to work at the housing office as a grant writer and administrator who helped the office's credit counselor in his work educating migrants about the US mortgage and credit markets. In addition to this work, I volunteered at a Catholic mission that aids Mexican migrants and on a committee to create a Mexican community center. Through my volunteer work I also developed relationships with social service workers and local business and government leaders. Perhaps most significantly, my volunteer work allowed me to meet a core group of seven families whom I visited several times a week. I became close to these families, engaging in a range of activities from formal interviews to everyday socializing. It was the relatives of these families who helped me build my life in Uriangato.

In Uriangato I continued to give back by offering free ESL classes, which I designed at the behest of parents who wanted their children to learn English. Many Uriangatense parents see the acquisition of English as key to their children's future mobility, whether as migrants or in the local textile industry. The English language learning centers in Uriangato are cost prohibitive for the working-class families whose lives are at the heart of this ethnography. Using the materials that I had developed for my classes in Chester County, I ran two free weekly classes for children in the neighborhood where I lived in Uriangato. At the request of one of the fathers I knew, who worked as a security guard at Uriangato's technical institute where his son was a student, I also taught an advanced English conversation class to twenty college-aged students. This enabled me to build social relations with middle-class students and teachers, whose perspectives on migration helped me discern the uniquely working-class experience of migration, detailed throughout this book.

Beyond teaching, I also took on an informal role in the neighborhood advising mothers on their right to receive child support from their spouses in the United States. While in Chester County, I had learned from Mexican consular officials that Mexico and the United States have a bilateral agreement that allows Mexican consulates to garnish the wages of delinquent migrant fathers and send them to their spouses in Mexico. I helped several mothers apply for and receive support through this program. In fact, I became so well known for this work on the block 
where I lived that my friends teased me as I was getting ready to return to the United States that I should stay and open up an office offering this service.

\section{Methods of Data Collection}

My methods of data collection and analysis involved a combination of participant observation, captured in daily field notes, survey and ethnographic interviews, and a linguistic anthropological approach to the close textual analysis of discourse as interaction. Between 2000 and 2005 I compiled thirty field-note journals, which I subsequently typed up and organized by theme. In Chester County my ability to conduct the classical participant observation that Clifford Geertz (1998) famously described as "deep hanging out" was circumscribed by the rhythm of life for migrants: long work hours and the social isolation typical of US suburbia. While I was able to engage in a range of activities with peopleand especially with the families I came to know well-my ability to participate in and observe people's lives was contained within my volunteer work and my weekly experiences with the families at the center of my research. In contrast, my research in Uriangato was conducted in the context of more classical participant observation, with its deep hanging out. As such, my ethnographic experience in Uriangato was more fluid and full time than it was in Chester County. I lived with a family in the neighborhood where my research was grounded, and my participant observation was based in both the mundane routines and extraordinary events of my friends and research participants.

In Chester County and in Uriangato my interview work took two forms: open-ended ethnographic interviews lasting one to two hours and thirty-minute survey interviews, which were conducted in partnership with the Mexican Migration Project (MMP), discussed in chapter 2 (see also Dick 2006b). With a few exceptions, all interviews were conducted in Spanish, my second language. In Chester County I completed 30 ethnographic interviews between 2000 and $200 \mathrm{I}$ and I7 MMP interviews in 2003. In Uriangato I completed 48 ethnographic interviews and I70 MMP interviews between $200 \mathrm{I}$ and 2002. All of my ethnographic interviews were audio-recorded and subsequently transcribed and translated by me, in a few cases with the support of my undergraduate research assistants at Arcadia University. A majority of the survey 
interviews were not audio-recorded; instead, information was noted by hand on the MMP survey questionnaire. I received permission from the MMP to audio-record these interactions, however, if interviewees agreed; I was able to record roughly 20 percent of the survey interviews.

In my interview work, I primarily engaged migrants and their relations, although in each locale I also conducted ethnographic interviews with government officials, social service workers, and employers, who provided me information about the history and political economies of both locations. My ethnographic interviews with migrants and their relations were almost always conducted with people I knew well and involved a series of questions evaluating life in Mexico and the United States, which I had developed inductively through my informal conversations with research participants. I enlisted the help of close friends who gave me feedback on the questions, letting me know if my Spanish was comprehensible and resonant with the ways Uriangatenses talk about migration. By contrast, the MMP survey interviews were-by design - conducted with people I did not know and followed a protocol developed by the MMP, which asks a series of questions about work and migration history and the educational and income level of households (see Dick 2006b; Massey et al. I987 for a description). For some households that I met through the survey, I came to know members of those families well. I did both a survey interview and a subsequent ethnographic interview with some people, which led to some interesting results discussed elsewhere (Dick 2006b).

Part of the design of the MMP survey is to conduct follow-up interviews in the United States with the family members of people interviewed in Mexico, which meant contacting people at addresses provided by their relations in Uriangato. In contrast to my experience in Uriangato, where I discovered-to my surprise-that people were very willing to participate in the survey interviews, people in Chester County were quite reticent do so. Migrants in the United States are much more vulnerable to state intervention if they share information about their lives, so they were understandably wary of speaking with a person from the United States with whom they had no prior relationship. I was able to hire and train "Verónica," a woman whom I had met in Uriangato who had subsequently migrated to Pennsylvania. She and I had become close friends, and her help with the MMP interviews proved invaluable. She aided me in contacting households and attended all interviews, which helped people trust that I was not working for the US govern- 
ment or otherwise occupying some unsavory social role. Indeed, in my research, I needed to navigate carefully around a number of unflattering social positions, a process discussed at length in chapter 2 .

\section{Interviews}

I began my fieldwork intending to audio-record naturally occurring discourse, understood to be produced through interactions in which local meanings are created (Koven 20I4: 509; Potter 2002; Urban I991, 1996). I had originally planned for the interviews to supplement recordings of naturally occurring talk. But, although people were willing to be recorded in the context of an interview, I was unable to get permission to record interactions outside the interview frame. When it was time to socialize, it was time to put the recorder away (see chapter 2). To insist on recording noninterview talk would have risked my being read as a gringa, ${ }^{1}$ who only cares about work and does not understand the importance of sociality—a loaded framing that I had to avoid lest I be barred from social relations altogether, which would have made any kind of research impossible. I was not willing to take that risk, both as a practical concern and, more importantly, out of respect for the people who had graciously welcomed me into their lives. As a result, all of my recorded data are from interview interactions.

This research constraint forced me to think carefully about the place of interviews in the local "communicative ecology" (Shoaps 2009: 465; see also Briggs 2007) and about what kind of data interviews provide. Since the seminal critiques of the social science interview by Charles Briggs (I986) and Elliot Mishler (I986), qualitative researchers have turned a critical lens on this practice, spotlighting that interviews can occlude the perspectives of research participants and reinscribe power inequities (Koven 20I4). Moreover, interviews can be unfamiliar forms of interaction that grate against the speech genres of our research participants, inhibiting collection of accurate information and/or violating norms of appropriate behavior (Briggs 1986; Dick 2006b; Koven 20I4). As a result, some qualitative researchers eschew interviews because they are assumed to be unavoidably nonegalitarian and artificial (e.g., Potter 2002). By contrast, methods that allow the collection of naturally occurring data are favored, because they can make research more egalitarian and facilitate capturing data that exemplify the practices under study. Greg Urban, my dissertation supervisor, for example, got permis- 
sion from his research participants to spend the majority of his field research with a tape recorder hanging from his neck, running continually. Thus, he was able to record a range of spontaneous interactions, from routine talk to sessions of myth telling.

As a scholar whose intellectual home is linguistic anthropology, my inability to record noninterview interactions was alarming. Documenting interactions in field notes makes it difficult to complete the kind of careful textual analysis necessary for understanding how language and other semiotic practices not only reflect but also shape the social world-a underlying aim in nearly all sociocultural studies of language, including this book. In addition, interviews are ill suited for capturing certain kinds of exchanges. A project focused on the discursive analysis of religious rituals, for instance, would be very limited if the only recorded data were interview-elicited reports on such happenings. Yet I had to accept the limitations on my research and make the most of my interview data. This has proven much more productive than I initially imagined possible. My research aimed primarily to capture migrants' and nonmigrants' discourse about migration, which explains who migrates and positions actors with respect to "right" and "wrong" ways of migrating. Interview exchanges are well suited for this kind of metadiscursive rationalization, as illustrated in chapters 4 and 5 .

Moreover, as I show through the interactional analysis of interviews in these chapters, such exchanges often co-occur with breakthroughs to "natural exchanges," such as interruptions or narratives of personal experience (De Fina and Perrino 20II; Perrino 20II). Interviews are shaped by prior and anticipated discourse and by the social lives in which they are embedded, so they can be revealing of these processes (Briggs 2007; De Fina and Perrino 20I r; Koven 20I4; Perrino 20II). Sensitivity to these discursive relationships makes it possible to conduct interviews in ways that are interactionally recognizable and sensitive to power differentials (Briggs 1986). Furthermore, interviews are not necessarily foreign to local communicative ecologies: they can themselves be naturally occurring. Indeed, as I argue in chapter 2, the migrant enclaves of Chester County and Uriangato are "interview societies" (Briggs 2007: $55^{2}$ ): social milieus in which interviews are familiar interactions recognized as sites for the production of consequential information.

Nonetheless, it bears emphasizing that Words of Passage is not an "interview-based study." Its insights are not derived from my interviews alone but from the triangulation of these data with other kinds of in- 
formation. Because I am able to situate my recorded data inside of my participant observation and involvement with the lives of Uriangatenses over many years, I am able to analyze my interviews inside these relationships and the other interactions that I recorded in field notes. Indeed, I not only developed the questions in my ethnographic interviews out of the propositions and framings of everyday talk about migration but also carefully coordinated analysis of the interviews with the resonant themes of such discourse, which I surmised from processing my field notes. When I transcribed the recorded interviews, I organized them not only by theme but by certain discursive practices that I noticed recurring, such as the gendered patterns of pronominal usage discussed in chapters 4 and 5. This allowed me to track the overarching patterns in Uriangatense migration discourse and calibrate it with the noninterview talk that I had documented in field notes, showing robust similarities between the talk of migration recorded in interviews and discourse from other interactions (Dick 2017).

Moreover, I was able to share portions of the interviews with my research participants (always being careful not to identify speakers, by using pseudonyms and decontextualizing the discourse excerpts) and-subsequently_with two of my undergraduate research assistants-Camilo López Delgado and Bryan Mier, who are native speakers of Spanish—to ascertain their interpretations of the interactions and coordinate/revise my own accordingly (cf. Koven 2007). I also document the similarities and differences between interview discourse and discourse produced by state-actors and journalists. Between 2000 and 2005 I built a database of local and national newspaper articles and speeches of government officials related to migration, which supports my analysis in chapters I and 2. Finally, this book considers more than people's talk of migration. It imbricates analysis of such talk not only with related forms of discourse (in particular immigration and economic policy) but with other semiotic practices that inform Mexicanidad, especially home construction (chapter 3 ) and the Catholic cult of the saints (chapter 5).

\section{Naming and Protecting Identities}

Because migrants-especially Mexican migrants in the United Statesare often subject to state surveillance and other kinds of monitoring, which can be devastating for family networks, it is important to take 
measures to protect their identities. In accordance with the Mexican Migration Project (MMP) protocol, the survey data I collected in Uriangato were randomized: each household was assigned a number and was sorted by an Excel program; no other identifying feature was assigned to these homes. The survey data I collected in Pennsylvania came from people related to members of the MMP households in Uriangato, though they were similarly de-identified with a number. Once the surveys were completed, I returned them to the MMP. The information was compiled into aggregate statistical data, stored by the MMP. As mentioned above, I received permission from the MMP to record some of the survey interviews but gathered no names during these recordings, identifying the household only by its number. Consent for all research interactions, including interviews, was obtained orally. Asking people to sign consent forms-especially in the United States, where people are often wary of "official exchanges" signaled by documents because of concerns about legal status-would have presented an insurmountable barrier to research. For my qualitative data (both my field notes and ethnographic interviews), I assigned each research participant a pseudonym. For public or historical figures, I use actual names; all other names in this book are pseudonyms. Moreover, to protect my research participants in the United States, I do not name any particular town but refer to the site in aggregate as "Chester County." People residing in Mexico are much less vulnerable to direct threats to their wellbeing from the government or fellow residents as a result of migration, so I have not changed the name of the city where I concentrated my research there. Moreover, because it is necessary to describe the political economic history of Uriangato, which distinguishes it from similar cities in Mexico, it would be immediately identifiable even with a pseudonym. However, I have changed the name of the neighborhood where I grounded my life and research and conducted the MMP survey, calling it "La Libertad." I have also altered all street names and other salient details about the particular locations of households. Finally, out of respect for my relationships with the people with whom I grew closest, I chose to base the extended analysis of conversations in chapters 4 and 5 on interactions with people with whom I was not as close. To do an analysis of a conversation with a close friend felt like a violation of intimacythough the perspectives of these people, in particular the members of my host family and my friend Elena and her family, inform every aspect of this book and appear narratively throughout. 
xxviii Technical Note

\section{Translation and Transcription Conventions}

I compiled the majority of the translations of my recorded data by myself. The material analyzed in chapter 5 was translated in collaboration with my research assistants Camilo López Delgado and Bryan Mier. For transcriptions of my recordings, I used the following conventions, which are standard in the field (e.g., Du Bois 2007).

\begin{tabular}{cl} 
Transcription Key & \\
\hline Symbol & Meaning \\
\hline A & Don Arturo (chapter 4) \\
$B$ & Belén (in italics) (chapter 5) \\
C & Doña Cecilia (in italics) (chapter 4) \\
$H$ & Hilary (in bold) (chapters 4 and 5) \\
M & Magdalena (chapter 5) \\
R & Rigoberto (chapter 5) \\
- & Interruption \\
\{\} & Interpolations \\
{[]} & Simultaneous speech \\
$\ldots$ & Pause \\
$\varnothing$ & Discourse pattern not found \\
\hline
\end{tabular}

